\title{
Enhancing performance and sport injury prevention in disability sport: moving forwards in the field of football
}

\author{
Osman Hassan Ahmed, ${ }^{1,2}$ Ayser W Hussain, ${ }^{1,3}$ Ian Beasley, ${ }^{1}$ \\ Jiri Dvorak, ${ }^{4}$ Richard Weiler ${ }^{1,5}$
}

\section{IMPLEMENTATION-CHALLENGING IN ABLE-BODIED SPORT-MORE SO IN DISABILITY SPORT}

According to the $\mathrm{WHO}$, approximately $15.6 \%$ of the world population live with some form of disability, including 70 million children world-wide aged between 15 and 18 years. ${ }^{1}$ The benefits of exercise for individuals living with disability have been highlighted in the literature, ${ }^{2}$ and participation in team sports, such as football, provides additional benefits (such as facilitating social inclusion, creating peer group networks and challenging perceived social stereotypes). While prevention of injury is an important issue for all athletes, the impact of a sporting injury to an individual with a disability may severely affect their ability to function independently on a daily basis. For example, an athlete with a lower limb amputation who sustains a major injury such as an ACL and osteochondral injury could suffer long-term health consequences. In addition, gaining access to healthcare services and rehabilitation may be more challenging for individuals with a disability. ${ }^{3}$ Given the many health and social benefits of sporting participation in the disabled population and the additional barriers to their involvement, ${ }^{4}$ it is essential that measures are taken to help better understand injury prevention ${ }^{5}$ and make sport safer for athletes with a disability.

Recent papers on sports injury prevention in BJSM have centred on methods for translating research into practice. ${ }^{6} 7$ The

\footnotetext{
${ }^{1}$ The FA Centre for Disability Football Research, St Georges Park, Burton-Upon-Trent, UK; ${ }^{2}$ Centre for Health, Activity and Rehabilitation Research, School of Physiotherapy, University of Otago, Dunedin, Otago, New Zealand; ${ }^{3}$ Department of Exercise and Sport Science, Institute for Performance Research, Manchester Metropolitan University, Cheshire, UK; ${ }^{4}$ F-MARC (FIFA Medical Assessment and Research (entre), Zurich, Switzerland; ${ }^{5}$ University College London Hospitals NHS Foundation Trust, London, UK

Correspondence to Dr Osman Hassan Ahmed, The FA Centre for Disability Football Research, St Georges Park, Burton-Upon-Trent, DE13 9PD, UK; osman. hassan.ahmed@gmail.com
}

primary focus of such injury prevention research has been directed towards ablebodied sport, ${ }^{8}$ using frameworks based on best-practice knowledge and evidence. Although many generic sports injury prevention paradigms may be applied to disability sport, athletes with a disability often already have pre-existing ranges of complex impairments which pose additional challenges to safe sporting participation. Furthermore, each of these impairment types generate specific considerations which impact on the potential for risk of injury. ${ }^{10}$ Injury prevention principles such as correction of muscle imbalance and improving gait are important components in sports injury prevention. ${ }^{11}$ However many athletes with disability (eg, athletes with amputations or athletes with cerebral palsy) have long-standing and non-modifiable muscle and gait imbalances, meaning that injury prevention approaches for these athletes would need to be specifically tailored to their level of function. Examples of specific injury prevention programmes for athletes with a disability are uncommon but there have been some reported instances of these innovations in the field of Paralympic sport. ${ }^{12}$

Current strategies and approaches to assist sport injury prevention ${ }^{9}$ in mainstream sport have yet to be adapted, validated or made specific to disability football. A non-exhaustive search by three of the authors (RW, OHA and AWH) using traditional sources (Scopus, PubMed) and emerging sources (YouTube, Apple's iTunes store) only retrieved two published epidemiological studies which discussed injury prevention in disability sport. $^{12} 13$ Despite van Mechelen et al ${ }^{14}$ demonstrating that there are numerous smartphone applications (apps) targeted towards injury prevention, none of these apps cater to the athlete with a disability. Paradoxically, injury audit data has demonstrated that visually impaired football contained some of the highest injury rates across all sports that competed during the 2012 Paralympic games. ${ }^{15}$
FA CENTRE FOR DISABILITY FOOTBALL RESEARCH

In light of this finding and the considerations related to injury prevention in disability football, the Football Association in England has recently established the 'FA Centre for Disability Football Research' (FA CDFR). The FA CDFR has been assembled to conduct research within the versions of disability football that are supported by The Football Association including: cerebral palsy, hearing impaired, visually impaired, partially sighted, learning disability and wheelchair football. In keeping with efforts to increase injury surveillance studies in football, ${ }^{16}$ The FA Injury and Illness Surveillance Study is collecting epidemiological data on all the Football Association representative squads. This has been tailored by the FA CDFR to include injury and illness data from the disability football squads and will inform future research within the FA CDFR, which will focus on reducing the risk of injury and improving performance. The FA CDFR shares aspirations and commitment to FIFA's 'Football for Health' ${ }^{17}$ and 'Football for Hope'. ${ }^{18}$ The FA CDFR is looking forward to disseminating its research findings to the international football and disability football communities.

Acknowledgements The authors would like to thank Jeff Davis, Anna Hurley, Dr John Iga and Gary Lewin at The Football Association for their assistance and support in establishing the FA CDFR. They also acknowledge and thank Dr Aileen Taylor for her work undertaken on the FA Injury and IIIness Surveillance Study.

Contributors OHA, RW and AWH conceptualised the paper and prepared the preliminary draft of the manuscript. IB and JD approved the final version of the manuscript.

\section{Competing interests None.}

Provenance and peer review Not commissioned; externally peer reviewed.

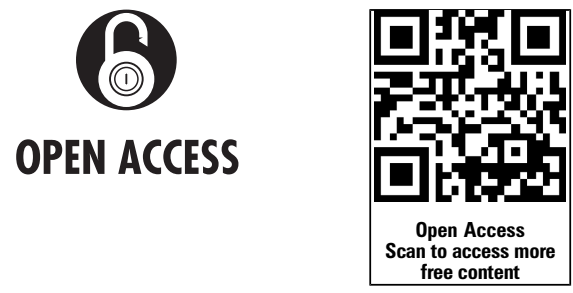

Open Access This is an Open Access article distributed in accordance with the Creative Commons Attribution Non Commercial (CC BY-NC 4.0) license, which permits others to distribute, remix, adapt, build upon this work non-commercially, and license their derivative works on different terms, provided the original work is properly cited and the use is non-commercial. See: http:// creativecommons.org/licenses/by-nc/4.0/

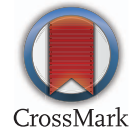

To cite Ahmed $\mathrm{OH}$, Hussain AW, Beasley I, et al. $\mathrm{Br} J$ Sports Med 2015;49:566-567. 
Received 5 September 2013

Revised 30 January 2014

Accepted 31 January 2014

Published Online First 21 February 2014

Br J Sports Med 2015;49:566-567.

doi:10.1136/bjsports-2013-093058

\section{REFERENCES}

1 World Health Organisation. World report on disability. Geneva, Switzerland: World Health Organisation, 2011.

2 Froehlich-Grobe K, Lee J, Washburn R. Disparities in obesity and related conditions among Americans with disabilities. Am J Prev Med 2013;45:83-90.

3 Kroll T, Jones GC, Kehn M, et al. Barriers and strategies affecting the utilisation of primary preventive services for people with physical disabilities: a qualitative inquiry. Health Soc Care Comm 2006; 14:284-93.

4 Rimmer JH, Riley B, Wang E, et al. Physical activity participation among persons with disabilities: barriers and facilitators. Am J Prev Med 2004;26: 419-25.
5 Thompson W, Vanlandewijck YC. Science and the paralympic movement. Br J Sports Med 2013;47:811.

6 Donaldson A, Finch C. Applying implementation science to sports injury prevention. Br I Sports Med 2013:47:473-75.

7 Berge $H_{1}$ Clarsen B. Sports injury prevention: mission possible! Br J Sports Med 2013;47:467-8.

8 White P, Otago L, Saunders N, et al. Ensuring implementation success: how should coach injury prevention education be improved if we want coaches to deliver safety programmes during training sessions? Br J Sports Med 2014;48:402-3.

9 Verhagen $E$, Voogt $N$, Bruinsma $A$, et al. A knowledge transfer scheme to bridge the gap between science and practice: an integration of existing research frameworks into a tool for practice. Br J Sports Med 2014;48:698-701.

10 Webborn N. Lifetime injury prevention: the sport profile model. Br J Sports Med 2012;46:193-7.

11 Croisier J, Ganteaume S, Binet J, et al. Strength imbalances and prevention of hamstring injury in professional soccer players: a prospective study. Am J Sports Med 2008;36:1469-75.

12 Webborn N, Willick S, Emery C. The injury experience at the 2010 winter paralympic games. Clin I Sport Med 2012;22:3-9.
13 Ferrara M, Buckley WE, McCann BC, et al. The injury experience of the competitive athlete with a disability: prevention implications. Med Sci Sports Exerc 1992;24:184-8.

14 van Mechelen D, van Mechelen W, Verhagen E. Sports injury prevention in your pocket?! Prevention apps assessed against the available scientific evidence: a review. Br J Sports Med 2014;48:878-82.

15 Willick S, Webborn N, Emery C, et al. The epidemiology of injuries at the London 2012 Paralympic Games. Br I Sports Med 2013;47:426-32.

16 Ekstrand J, Dvorak J, D'Hooghe M. Sport medicine research needs funding: the International football federations are leading the way. $\mathrm{Br} /$ Sports Med 2013;47:726-8.

17 FIFA.com. Football for Health. 2013 [cited 2013 1st July 2013]. http://www.fifa.com/aboutfifa/ footballdevelopment/medical/aboutus/fmard footballforhealth.html

18 FIFA.com. Football for Hope. 2013 [cited 2013 3rd July]. http://www.fifa.com/aboutfifa/ socialresponsibility/footballforhope/mission.html 